\title{
Acetylcholine Receptor Antibody Measurement
}

National Cancer Institute

\section{Source}

National Cancer Institute. Acetylcholine Receptor Antibody Measurement. NCI

Thesaurus. Code C96559.

The determination of the amount of acetylcholine receptor antibody present in a sample. 